2. To: (Receiving Organization)

Distribution

5. Proj./Prog./Dept./Div.:

Project W-519

8. Originator Remarks:

Attached is the Year 2000 Compliance Assessment for Project W-519.

11. Receiver Remarks:

11A. Design Basel ine Document?
3. From: (Originating Organization) 83100/TWRS Upgrades

6. Design Authority/ Design Agent/Cog. Engr.: JH Busse 11
4. Related EDT No.:

$N / A$

7. Purchase Order No.:

$$
N / A
$$

9. Equip./Component No.: $\mathrm{N} / \mathrm{A}$

10. System/Bldg./Facility: Year 2000/241-G

12. Major Assm. Dwg. No.: $N / A$

13. Permit/Permit Application No.: $\mathrm{N} / \mathrm{A}$

14. Required Response Date: N/A

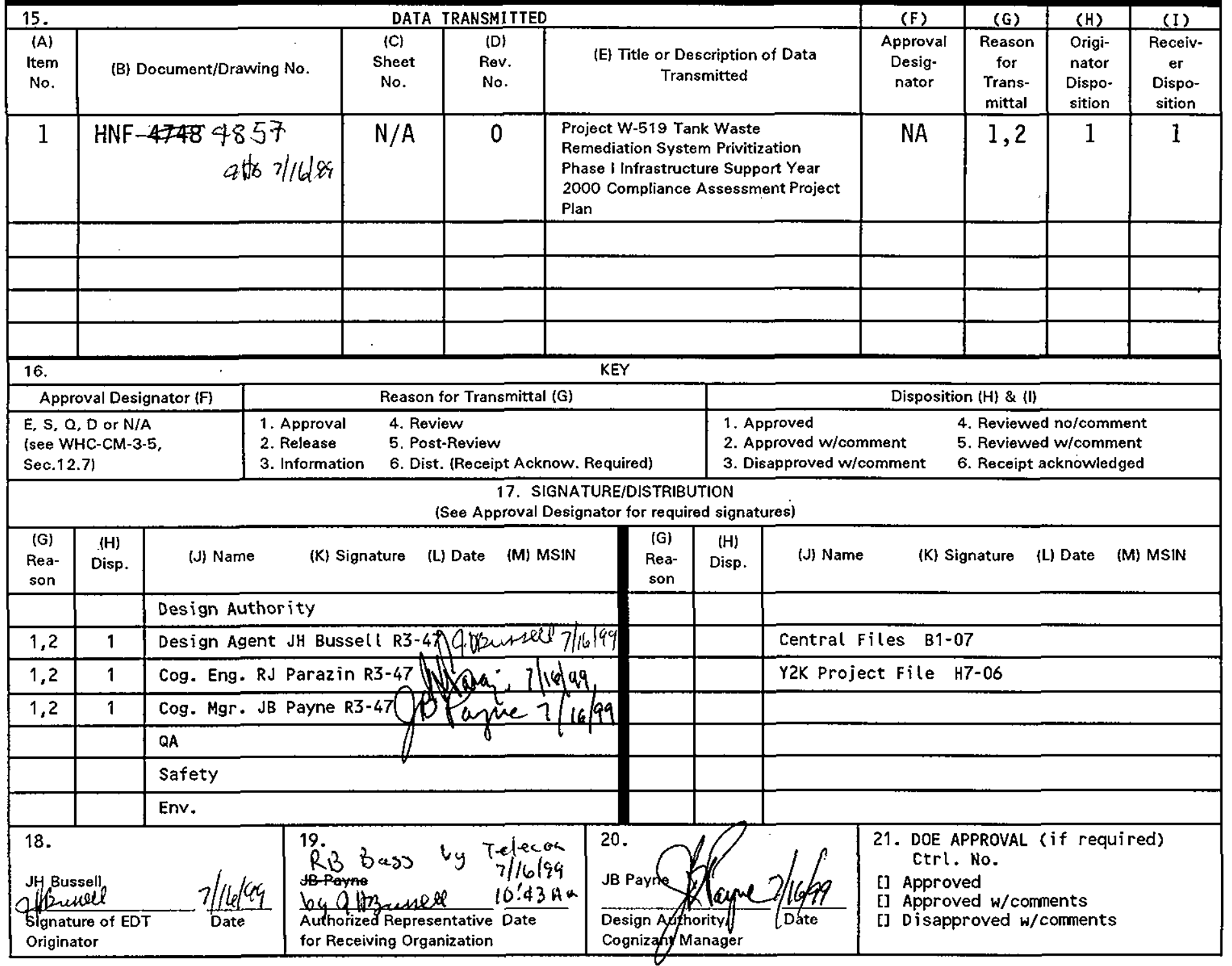




\title{
PROJECT W-519 TWRS PRIVITIZATION PHASE I INFRASTRUCTURE YEAR 2000 COMPLIANCE ASSESSMENT PROJECT PLAN
}

\section{J. H. Bussell}

Numetec

Richland, WA 99352

U.S. Department of Energy Contract DE-AC06-96RL13200

\author{
EDT/ECN: 626715 \\ UC: 2030 \\ Org Code: 83100 \\ B\&R Code: EW02J123 \\ Total Pages: 7
}

Key Words: Year 2000, Y2K, Project W-519

Abstract:

This document contains a limited assessment of Year 2000 compliance for Project $W-519$. Additional information is provided as a road map to project documents and other references that may be used to verify Year 2000 compliance.

TRADEMARK DISCLAIMER. Reference herein to any specific commercial product, process, or service by trade name, trademark, manufacturer, or otherwise, does not necessarily constitute or imply its endorsement, recommendation, or favoring by the United States Government or any agency thereof or its contractors or subcontractors.

Printed in the United States of America. To obtain copies of this document, contact: Document Control Services, P.O. Box 950, Mailstop H6-08, Richland WA 99352, Phone (509) 372-2420; Fax (509) 376-4989.
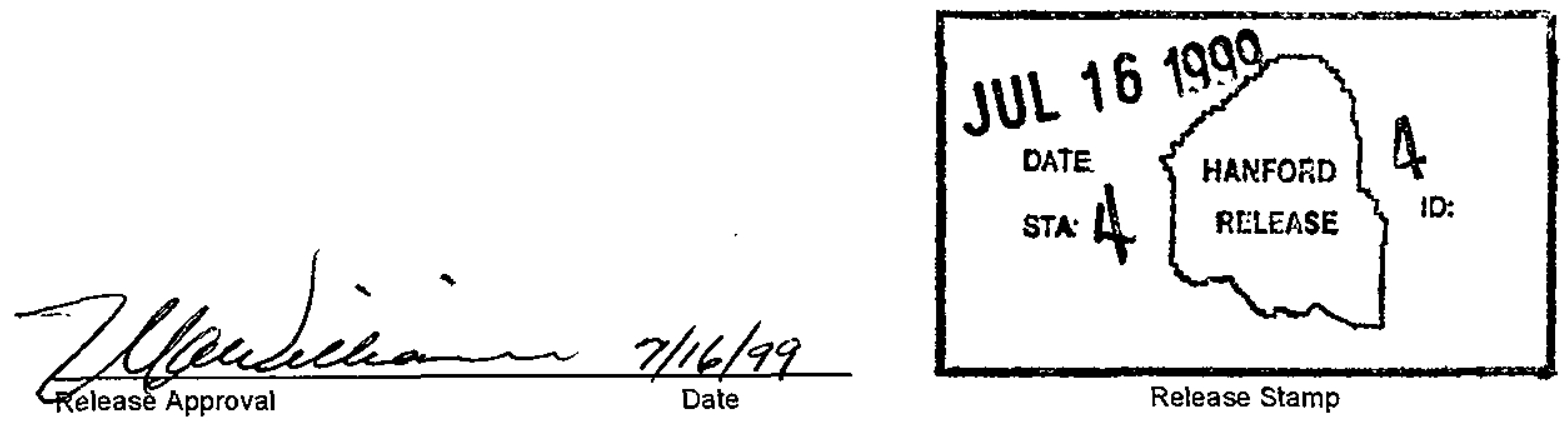

Release Stamp 
PROJECT W-519

\section{TANK WASTE REMEDIATION SYSTEM PRIVITIZATION PHASE I INFRASTRUCTURE SUPPORT}

\section{YEAR 2000 COMPLIANCE ASSESSMENT PROJECT PLAN}

Prepared by:

JH Bussell

Numatec Hanford Co.

July 15, 1999 


\section{TABLE OF CONTENTS}

1.0 SCOPE

2.0 GENERAL SYSTEM DESCRIPTION 4

2.1 Electrical Power System 4

2.2 Raw, Potable, Fire Water Systems. 4

2.3 Site Development and Roads 4

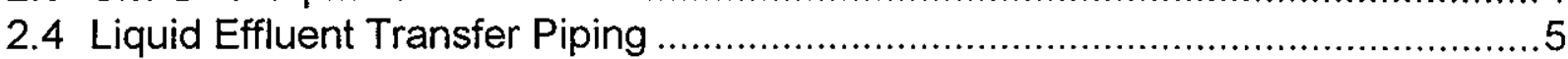

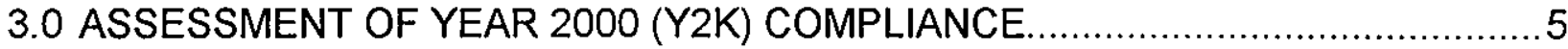

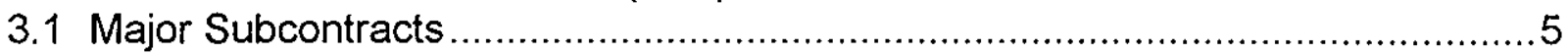

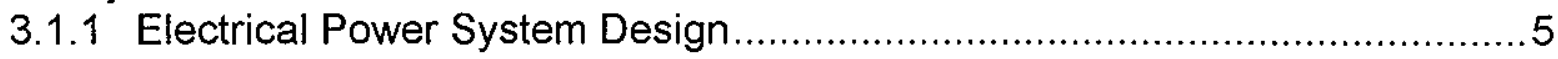

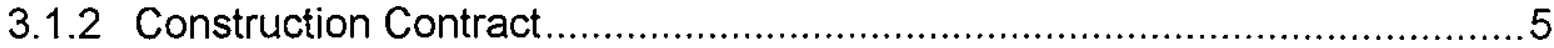

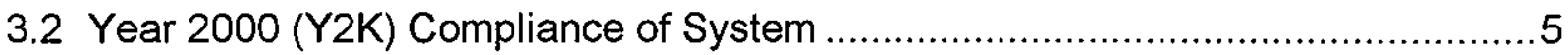

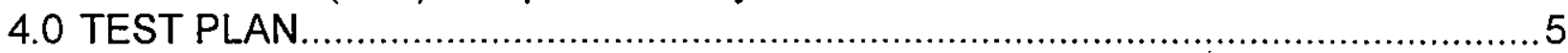

5.0 YEAR 2000 (Y2K) ACTIVITIES, MAJOR MILESTONES, AND DELIVERABLES .....5

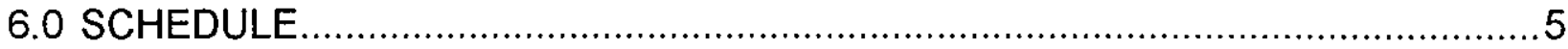

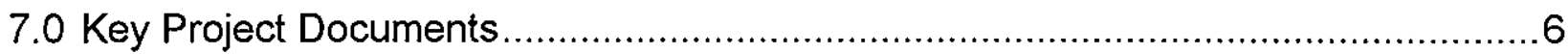




\subsection{SCOPE}

This assessment describes the potential Year 2000 (Y2K) problems and describes the methods for achieving Y2K Compliance for Project W-519, Tank Waste Remediation System Privitization Phase I Infrastructure Support. The purpose of this assessment is to give an overview of the project. This assessment will describe the methods, protocols, and practices to assure that equipment and systems do not have $\mathrm{Y} 2 \mathrm{~K}$ problems. This document will not be updated and any dates contained in this document are estimates and may change. The scope of project $W-519$ is to provide utilities and infrastructure to support construction and operation of the private contractor's facility to treat, immobilize, and dispose of tank waste. The private contractor's facility will be located on east side of 200E-area and north of Route $4 \mathrm{~S}$ (near the defunct grout vaults). The utilities include potable and process water, construction and operational electrical power systems, and liquid effluent disposal transfer lines to the existing effluent treatment facility (ETF) and the liquid effluent retention facility (LERF).

\subsection{GENERAL SYSTEM DESCRIPTION}

\subsection{Electrical Power System}

The electrical power system installation consists of two parts. The first part is to provide construction power ( 7 Megawatts, $13.8 \mathrm{kV}$ ) to the private contractor's construction site. The second part of the electrical power system installation will install a new $230-13.8-k V$ substation and two $230-k V$ transmission-line segments (3.5 miles). Supervisory control and data acquisition (SCADA) system will be installed during the second part. This equipment may contain equipment that may process dates or contain real-time clocks. Procurement of equipment and materials is scheduled to start in October 1999. Most of the materials purchased before January 2000 will be long lead procurement items such as large power transformers.

Procurement of items extends to January 2001.

\subsection{Raw, Potable, Fire Water Systems}

Non-potable water (raw water) will provided from an existing standpipe. Raw water for process and fire protection purposes will be installed for the private contractor's facility. Water meters will be installed in the potable and raw water supply to measure the water usage by the private contractor.

\subsection{Site Development and Roads}

Approximately 55 acres will be cleared and graded in preparation for the private contractor's facility. The roadway at the intersection of Canton Street and Route $4 S$ will be widened and an acceleration lane will also be added. A loop road will be construct around the proposed location of the private contractor's facility. 


\subsection{Liquid Effluent Transfer Piping}

Liquid effluent piping will be installed from the ETF/LERF to the proposed site of the private contractor's facilities.

\subsection{ASSESSMENT OF YEAR 2000 (Y2K) COMPLIANCE}

\subsection{Major Subcontracts}

\subsubsection{Electrical Power System Design}

An engineering firm has been selected to design and build the new 230-13.8 kV substation and the two $230-\mathrm{kV}$ transmission-line segments. Construction will not start until March 2000 with long lead-time procurements to start in October 1999.

\subsubsection{Construction Contract}

A construction firm will be selected to perform the site grading, road construction, installation of water lines, and installation of liquid effluent transfer lines.

\subsection{Year 2000 (Y2K) Compliance of System}

As described above the SCADA system for the electrical system may contain real time clocks. However, this equipment will be installed after January 2000. Procurement of this equipment has not started. Procurement clauses will be added to procurement documentation requiring that equipment or components to be $\mathrm{Y} 2 \mathrm{~K}$ compliant.

Data acquisition systems, communication equipment (modems), and process instruments will be purchased to implement a leak detection system for liquid effluent transfers from the private contractor's facility to the ETF and LERF. Design for this equipment has not started. Procurement clauses will be added to procurement documentation requiring that equipment or components to be $\mathrm{Y} 2 \mathrm{~K}$ compliant.

\subsection{TEST PLAN}

No special testing $\mathrm{Y} 2 \mathrm{~K}$ testing is planned. However, all applicable $\mathrm{Y} 2 \mathrm{~K}$ related dates will be tested as part of the system acceptance testing.

\subsection{YEAR 2000 (Y2K) ACTIVITIES, MAJOR MILESTONES, AND DELIVERABLES}

No special activities are planned.

\subsection{SCHEDULE}

No special activities are planned for project. Construction of site roads, installation of raw and potable water lines are scheduled to start in August 1999. The substation and power transmission line construction is scheduled to start in April 2000. Construction of the liquid effluent transfer lines is scheduled to start in October 2000. 


\subsection{Key Project Documents}

BNFL, 1996, Contract, "TWRS Privatization Contract", British Nuclear Fuels Limited (BNFL), DE-AC06-96RL13308, Richland, Washington.

Crane, A. F., 1997, "Interface Control Document, 200 Area Treated Effluent Disposal Facility Interface Control Document," HNF-SD-W049H-ICD-001, REV. 4, Rust Federal Services of Hanford, Inc., Richland, Washington.

Delannoy, C. R., Project W-519 TWRS Privitization Phase I Traffic Study," HNF-3466, Rev. 0, Dyncorp, Inc., Richland, Washington.

DOE/RL, 1994, "RCRA, Part A, Dangerous Waste Permit Application, "DOE/R-88-21.

Ecology, EPA, and DOE, 1994, "Hanford Federal Facility Agreement and Consent Order," as amended, Washington State Department of Ecology, U.S. Environmental Protection Agency, and U.S. Department of Energy, Olympia, Washington.

Fort, D. L., 1996, "Design Requirements Document for TWRS Privatization Phase I Liquid Effluent Transfer Systems," WHC-SD-WM-DRD-014, Rev. 1, Numatec Hanford Co., Richland, Washington.

Graves, C. E., 1996a, "Interface Control Document, Interface Control Document for Electricity," WHC-SD-WM-ICD-036, Rev. 0, Westinghouse Hanford Company, Richland, Washington.

Graves, C. E., 1996b, "Interface Control Document, Interface Control Document for Raw Water," WHC-SD-WM-ICD-034, Rev. 0, Westinghouse Hanford Company, Richland, Washington.

Graves, C. E., 1996c, "Interface Control Document, Interface Control Document for Potable Water," WHC-SD-WM-ICD-035, Rev. 0, Westinghouse Hanford Company, Richland, Washington.

Graves, C. E., 1996d, "Interface Control Document, Interface Control Document for Land for Siting," WHC-SD-WM-ICD-037, Rev. 0, Westinghouse Hanford Company, Richland, Washington.

Graves, C. E., 1996e, "Interface Control Document, Interface Control Document for Untreated Liquid Effluents, "WHC-SD-WM-ICD-038, Rev. 0, Westinghouse Hanford Company, Richland, Washington.

Graves, C. E., 1996f, "Interface Control Document, Interface Control Document for Treated Liquid Effluents," WHC-SD-WM-ICD-039, Rev. 0, Westinghouse Hanford Company, Richland, Washington. 
Huston, J. J., 1999, "Tank Waste Remediation Phase I Infrastructure, Quality Assurance Implementation Plan," HNF-4386, Rev. 0, Numatec Hanford Co., Richland, Washington.

ICF KH, 1996, Letter Report, Tank Waste Remediation System Privatization Phase I, Water Balance Analysis, E23385LR, ICF Kaiser Hanford Company, Richland, Washington.

Mitchell, R. M., Markes, B. M., Skoglie, D. E., 1998, "Tank Waste Remediation System Phase 1 Infrastructure Project W-519 Characterization," HNF-3210, Rev. 0, Waste Management Hanford Co., Richland, Washington.

Parazin, R. J., 1998a, "Project W-519 CDR Supplemental Raw Water \& Electrical Services for Privatization Contractor AP Tank Farm Operations, HNF-2703, Rev. 0 , Numatec Hanford Co., Richland, Washington.

Parazin, R. J., 1998b, "Tank Waste Remediation System Privatization Phase 1 Infrastructure Project W-519 Project Execution Plan," HNF-2811, Rev. 0, Numatec Hanford Co., Richland, Washington.

Parazin, R. J., 1998c, "Design Requirements Document for TWRS Privitization Phase I Site Development," HNF-SD-WM-DRD-013, Rev. 2, Numatec Hanford Co. Richland, Washington.

Parazin, R. J., 1998d, "Project W-519 Water Balance Analysis for Raw Water System," HNF-3363, Rev. 0, Numatec Hanford Co., Richland, Washington.

Parazin, R. J. 1999, "TWRS Privatization Phase I Master Site Plan," HNF-SD-TWR-DSD-001, Rev. 1, Numatec Hanford Co., Richland, Washington.

Singh, G., 1997a, "Design Requirements Document for Phase I Privatization Electrical Power System," WHC-SD-WM-DRD-011, Rev., 1, Numatec Hanford Co, Richland, Washington.

Singh, G., Fort, D. L., 1997a, "Summary Conceptual Design Report for TWRS Privatization Phase 1 Infrastructure Support Project W-519," HNF-1938, Rev. 0, Numatec Hanford Co. Fluor Daniel Hanford Northwest Co., Richland, Washington.

Singh, G., Hache, J. M., Henderson, J. L., 1999, "Design/Build Specification Project W-519 Privatization Infrastructure Support, Electrical Power System," HNF-2106, Rev. 1, Numatec Hanford Company, Richland, Washington. 